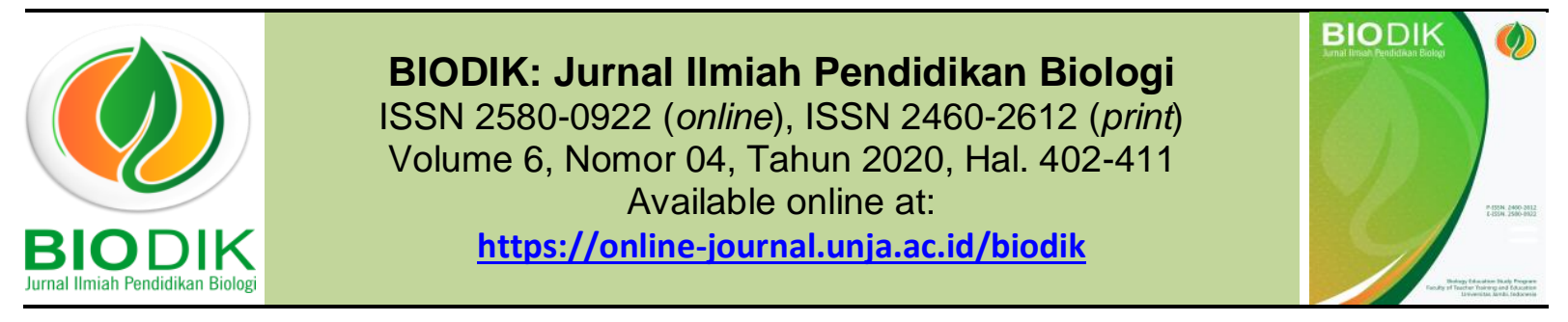

Research Article OPEN ACCESS

\title{
Pemanfaatan Nilai Struktur Vegetasi dan Nilai Serapan Karbon Mangrove Dalam Pengembangan Buku Ajar Ekologi Pesisir
}

\section{(Utilization the vegetation structure value and carbon absorption value of mangrove to develop the coastal ecological Teaching book)}

Ilyas H. Husalin ${ }^{1,2^{*}}$, Abubakar Sidik Katilii,2, Hartono D. Mamu' ${ }^{1,2}$

1 Jurusan Biologi, FMIPA, Universitas Negeri Gorontalo.

Jl. Jenderal Sudirman No. 6, Kota Gorontalo 96128, Provinsi Gorontalo-Indonesia

2Pusat Kajian Ekologi Pesisir Berbasis Kearifan Lokal Jurusan Biologi UNG.

Jl. Jenderal Sudirman No. 6, Kota Gorontalo 96128, Provinsi Gorontalo-Indonesia *Corresponding Authors: abubakarsidik@ung.ac.id

\begin{tabular}{|c|c|}
\hline Informasi Artikel & ABSTRACT \\
\hline $\begin{array}{l}\text { Submit: } 18-06-2020 \\
\text { Diterima: } 31-08-2020 \\
\text { Dipublikasikan: } 01-12-2020\end{array}$ & $\begin{array}{l}\text { This study aims to describe the effectiveness of using smartphone-based learning } \\
\text { media on ecosystem materials in developing students' environmental care attitudes. } \\
\text { This study aims to develop textbooks using the value of the structure of mangrove } \\
\text { vegetation and the value of carbon uptake. The value of the mangrove vegetation } \\
\text { structure value and the value of carbon uptake have been obtained from the results } \\
\text { of previous studies conducted in the mangrove area of Tabongo Village, Dulupi } \\
\text { District, Boalemo Regency, Gorontalo Province. In this study focused on the } \\
\text { development of coastal ecology textbooks based on the value of the mangrove } \\
\text { vegetation structure and its carbon absorption value. The method used is the 4-D } \\
\text { model (four D) which includes the defining stage, the planning stage (design), the } \\
\text { development stage (develop) and the dissemination stage. The dissemination stage } \\
\text { is carried out by implementing textbooks that have been developed in coastal ecology } \\
\text { lectures. The data was collected using a validation sheet, which includes material } \\
\text { validation, design validation, and legibility testing involving biology students. The data } \\
\text { obtained were analyzed using the formula for the average validation score, with the } \\
\text { eligibility criteria, namely very feasible (3.26 - } 4.00) \text {, feasible (2.51 - } 2.25), \text { quite } \\
\text { feasible (1.76 - 2.50), less feasible (1.00 - } 1.75) \text {. The research results obtained that, } \\
\text { the material expert's assessment of all aspects of assessment for textbook validation } \\
\text { is } 93.75 \% \text { which means that it has very good quality, because it is in the range of } \\
81 \% \text { to } 100 \% \text {, the design expert's assessment of all aspects of the assessment for } \\
\text { textbook design validation is } 91.67 \% \text { which means that the design quality is very } \\
\text { good, because it is in the range of } 81 \% \text { to } 100 \% \text {, the student response to the quality } \\
\text { aspects of textbooks is at a percentage of } 94 \% \text {, meaning this book is included in the } \\
\text { very good category because it is in the range of } 81 \text { to } 100 \% \text {. Thus, the textbook } \\
\text { produced in this study can be used as a reference in coastal ecology courses. } \\
\text { Keywords: : Mangrove vegetation, carbon sequestration, textbooks, coastal ecology }\end{array}$ \\
\hline Penerbit & ABSTRAK \\
\hline $\begin{array}{l}\text { Program Studi Pendidikan } \\
\text { Biologi, Fakultas Keguruan dan } \\
\text { Ilmu Pendidikan, Universitas } \\
\text { Jambi }\end{array}$ & $\begin{array}{l}\text { Penelitian ini bertujuan untuk mengembangkan buku ajar dengan menggunakan } \\
\text { materi nilai struktur vegetasi mangrove dan nilai serapan karbon. Nilai nilai struktur } \\
\text { vegetasi mangrove dan nilai serapan karbon telah diperoleh dari hasil penelitian } \\
\text { sebelumnya yang dilakukan di kawasan mangrove desa Tabongo Kecamatan Dulupi } \\
\text { Kabupaten Boalemo, Provinsi Gorontalo. Dalam penelitian ini difokuskan pada } \\
\text { pengembangan buku ajar ekologi pesisir yang berbasis pada nilai struktur vegetasi } \\
\text { mangrove dan nilai serapan karbonnya. Metode yang digunakan adalah model 4-D } \\
\text { (four D) yang meliputi tahapan pendefinisian (define), tahapan perencanaan } \\
\text { (design), tahapan pengembangan (develop) dan tahapan penyebaran (disseminate). }\end{array}$ \\
\hline
\end{tabular}


Untuk tahapan penyebarluasan dilakukan dengan mengimlementasikan buku ajar yang telah dikembangkan pada kegiatan perkuliahan ekologi pesisir. Pengumpulan data dilakukan dengan menggunakan lembar validasi, yang meliputi validasi materi, validasi desain, dan uji keterbacaan yang melibatkan mahasiswa biologi. Data yang diperoleh dianalisis dengan menggunakan rumus rata-rata skor validasi, dengan kriteria kelayakan yakni sangat layak $(3,26-4,00)$, layak $(2.51-2.25)$, cukup layak $(1,76-2,50)$, kurang layak $(1,00-1,75)$. Hasil penelitian yang diperoleh bahwa, penilaian ahli materi dari keseluruhan aspek penilaian untuk validasi buku ajar adalah $93.75 \%$ yang berarti memiliki kualitas sangat baik, karena berada pada rentang $81 \%$ sampai $100 \%$, penilaian ahli desain keselurah aspek penilaian untuk validasi desain buku ajar adalah $91.67 \%$ yang berarti memiliki kualitas desain sangat baik, karena berada pada rentang $81 \%$ sampai $100 \%$, respon mahasiswa untuk aspek kualitas buku ajar berada pada persentase $94 \%$ artinya buku ini termasuk pada kategori sangat baik karena berada pada rentang 81 sampai $100 \%$. Dengan demikian buku ajar yang dihasilkan dalam penelitian ini dapat dimanfaatkan sebagai salah satu referensi dalam mata kuliah ekologi pesisir.

Katakunci: Vegetasi mangrove, serapan karbon, buku ajar, ekologi pesisir

This BIODIK : Jurnal IImiah Pendidikan Biologi is licensed under a CC BY-NC-SA (Creative Commons Attribution-ShareAlike 4.0 International License)

\section{PENDAHULUAN}

Keanekaragaman hayati pesisir dan lautan Indonesia hadir dalam berbagai bentuk ekosistem, salah satunya adalah ekosistem mangrove. Mangrove merupakan tumbuhan halofil yang tidak dapat hidup dalam lingkaran bebas garam. Hal ini sejalan dengan pendapat Arief (2003) yang menyatakan bahwa mangrove adalah tumbuhan Halopytic vegetation atau tumbuhan yang memiliki kemampuan adaptasi tinggi terhadap salinitas payau dan harus hidup pada kondisi lingkungan yang demikian, sehingga spesies tumbuhannya disebut tumbuhan halophytes obligat. Mangrove merupakan sumber daya alam yang banyak ditemukan di kawasan pesisir, beberapa ahli juga mendefinisikan istilah "mangrove" secara berbeda-beda, namun pada dasarnya merujuk pada hal yang sama. Mangrove sebagai tumbuhan yang terdapat di daerah pasang surut maupun sebagai komunitas. Mangrove juga didefinisikan sebagai formasi tumbuhan daerah litoral yang khas di pantai daerah tropis dan sub tropis yang terlindung (Noor, 2012).

Mangrove memiliki manfaat sangat luas ditinjau dari aspek ekologi, biologi dan ekonomi. Fungsi ekologi antara lain menjaga kestabilan pantai dan sebagai habitat burung, fungsi biologi sebagai pembenihan ikan, udang dan biota laut pemakan plankton serta sebagai areal budidaya ikan tambak, areal rekreasi dan sumber kayu sebagai fungsi ekonomi. Menurut Bismark et al (2008) mangrove sebagaimana vegetasi hutan lainnya memiliki peran sebagai penyerap (rosot) karbondioksida (CO2) dari udara. Hal ini sejalan dengan pendapat Donato et al (2012) bahwa, diketahui mangrove memiliki kemampuan asimilasi dan laju penyerapan $C$ yang tinggi dimana dari hasil penelitian di 25 lokasi mangrove sepanjang Indo-Pasifik menunjukkan bahwa mangrove merupakan salah satu hutan terkaya karbon di kawasan tropis, yang mengandung sekitar $1.023 \mathrm{Mg}$ karbon perhektar dan sangat tinggi dibandingkan rerata simpanan karbon dari berbagai tipe 
hutan lainnya di dunia. Hal ini tentu terkait dengan fungsi ekologi mangrove secara tidak langsung. Mangrove menyerap sebagian karbon dalam bentuk $\mathrm{CO}_{2}$ yang di manfaatkan untuk proses fotosintesis, sedangkan sebagian lainnya tetap berada di atmosfer. Menurut IImiliyana (2012) selama dekade terakhir ini emisi $\mathrm{CO}_{2}$ meningkat dari 1400 juta ton per tahun menjadi 2900 juta ton pertahun. Dengan meningkatnya $\mathrm{CO}_{2}$ yang ada di atmosfer ini maka akan memicu terjadinya perubahan iklim secara global.

Salah satu fungsi ekosistem mangrove disamping fungsinya secara ekologis adalah fungsi sosial. Adanya fungsi ini dapat menunjang berbagai aktivitas sosial termasuk di dalamnya adalah dalam bidang pendidikan. Fungsi pendidikan ini mengarah pada memasukkan konsep-konsep menyangkut ekosistem mangrove menjadi salah satu konsep yang penting dalam pembelajaran mata kuliah ekologi pesisir. Berdasarkan hasil penelitian yang telah dilakukan oleh penulis sebelumnya, bahwa potensi vegetasi mangrove dan potensi serapan karbon yang terdapat di hutan mangrove, akan sangat bermanfaat apabila dijadikan bahan dalam mengembangkan pembelajaran. Materi yang berkaitan dengan hal ini adalah siklus beiogeokimia. Materi siklus biogeokimia di dalamnya terdapat sub materi yakni siklus karbon yang dihubungkan dengan hasil analisis kandungan karbon yang berada di sekitar hutan mangrove. Hal tersebut dapat dimanfaatkan dalam kegiatan perkulihan, khususnya dalam mata kuliah ekologi pesisir. Untuk mendukung hal teresebut, diperlukan sebuah instrumen berupa buku ajar yang telah dikembangkan dengan memasukkan di dalamnya materi tentang nilai struktur vegetasi mangrove dan nilai serapan karbon mangrove.

Hal ini selanjutnya akan memberikan implikasi bagi mahasiswa dalam perkuliahan dan dapat menajadikan kegiatan perkuliahan tersebut lebih bersifat kontekstual sehingga dapat mengarahkan mahasiswa dalam memahami konsepkonsep yang menayangkut struktur vegetasi mangrove dan nilai serapan karbon mangrove. Penelitian ini bertujuan untuk bertujuan untuk mengkaji nilai struktur vegetasi mangrove dan nilai serapan karbon yang dimanfaatkan untuk pengembangan materi pada mata kuliah ekologi pesisir dalam bentuk buku ajar. Urgensi penelitian ini terletak pada adanya pengembangan materi pada mata kuliah ekologi pesisir dan modivikasinya yang pada bagian akhir akan diperoleh sebuah buku ajar ekologi pesisir yang berbasis pada potensi nilai struktur vegetasi dan nilai serapan karbon mangrove.

\section{METODE PENELITIAN}

Penelitian ini merupakan penelitian pengembangan yang dalam bentuk penelitian research and development atau $\mathrm{R} \& \mathrm{D}$, yaitu suatu penelitian yang dilakukan dengan tujuan menghasilkan sebuah model, baik dalam bentuk perangkat keras (atau hardware) maupun perangkat lunak (software). Dalam penelitian ini 
produk yang dihasilkan adalah buku ajar pada mata kuliah ekologi pesisir dalam materi siklus biogeokimia sub materi yakni siklus karbon yang dihubungkan dengan hasil analisis kandungan karbon yang berada di sekitar hutan mangrove. Pengembangan Buku ajar ini dimaksudkan untuk meningkatkan kompetensi mahasiswa dalam mata kuliah ekologi pesisir. Prosedur penelitian pengembangan ini ditempuh melalui 10 langkah sebagaimana yang dikemukakan oleh Borg dan Gall (1989), yakni (1) mengumpulkan informasi dan melakukan penelitian awal (research andinformation collecting), (2) perencanaan (planning), (3) mengembangkan format atau model (developing preliminary form of product), (4) mempersiapkan uji coba tes di lapangan (preliminary field testing), (5) melakukan revisi terhadap tes berdasarkan hasil uji coba di lapangan (main product revision), (6) melakukan tes di lapangan (main field testing) (7) melakukan revisi setelah mendapatkan masukan dari tes lapangan (operational product revisions), (8) melaksanakan tes uji coba model atau tes pembelajaran (operational field testing), (9) melakukan revisi terakhir (final product revision), (10) menyampaikan laporan penelitian (dominition and implementation). Desain penelitian yang telah dikemukakan tersebut kemudian di sederhanakan atas tiga tahap, yaitu (1) tahap eksplorasi, (2) tahap pengembangan prototipe, dan (3) tahap validasi produk, adapun produk yang dihasilkan dalam penelitian ini adalah buku ajar (Faridi, 2008). Pengelompokan yang dilakukan menjadi tiga tahap tersebut bertujuan memudahkan dalam proses penelitian dan tidak mengurangi makna dari masing-masing langkah yang sebenarnya. Pengumpulan data dalam dilakukan dengan menggunakan instrumen. Instrumen yang digunakan dalam penelitian ini adalah angket yang diberikan kepada ahli konten/materi, ahli desain, dan mahasiswa jurusan biologi semester 4 yang memprogramkan mata kuliah ekologi pesisir sebagai respondennya. Berdasarkan instrumen tersebut diperoleh data yang dibutuhkan dalam penelitian dan pengembangan produk. Observasi digunakan untuk melihat kebutuhan yang diperlukan di lapangan.

\section{HASIL DAN PEMBAHASAN}

Penelitian pengembangan buku ajar pada mata kuliah ekologi pesisir merupakan suatu penelitian yang menghasilkan prototype buku ajar dari rangkaian penelitian yang telah dilakukan pada tahap sebelumnya yakni memperoleh data base degradasi hutan mangrove dan mengeeksplorasi spesies mangrove serta potensi nilai biomassa yang diserap oleh manrove yang selanjutnya pengembangan buku ajar ini merupakan pengembangan dari materi siklus biogeokimia. Buku ajar ini dikembangkan dengan mengacu pada adanya kebutuhan media cetak dalam pembelajaran ekologi pesisir sebagai salah satu mata kuliah wajib di jurusan pendidikan biologi FMIPA. Hasil desain buku ajar yang telah dilakukan dengan mengumpulkan bahan atau materi yang sesuai dengan indikator, kemudian mengintegrasikan materi dengan tugas-tugas yang harus dikerjakan oleh peserta didik. Materi serta tugas-tugas ini disusun secara sistematis berdasarkan komponenkomponen dalam buku ajar. Berikut adalah desain sistematika buku ajar. 


\begin{tabular}{|c|c|c|c|}
\hline Daftar Isi & & & \\
\hline & $\mathrm{Hal}$ & EPendugaan Nilai Serapan Karbon Mangrove di Desas & 79 \\
\hline KATA PENGANTAR & i & Jabonge Boaleme & \\
\hline DAFTARIS| & ii & BAB IV PERHITUNGAN SERAPAN KARBON & 86 \\
\hline DAFTAR GAMBAR & V & A Teknik Menghitung Biomassa & 86 \\
\hline DAFTAR TABEL & vii & a Teknik Dengan Pemanenan & 88 \\
\hline BABI EKOSISTEM MANGROVE & 1 & b Jeknik Janpa Pemanenan & 91 \\
\hline A Keragaman Kemposisi Jenis dan Struktur Hutan & 3 & c Pendugaan Dengan Penginderaan Jauh & 91 \\
\hline B Struktur dan Zonasi Mangrove & 7 & d Pembuatan Model & 92 \\
\hline CEakter Lingkungan Yang Mempengaruhi Ekosistem & & B Estimasi Biomassa Hutan & 92 \\
\hline Mangrove & 13 & aBiomass Expansion Factor (BEF) & 93 \\
\hline D Keterkaitan Eakter Lingkungan Eisik dengan Kondisi & 22 & $\begin{array}{l}\text { Deersamaan AlometoldK } \\
\text { CDesain Samnlino dan Prosedur Pelaksanaan }\end{array}$ & y/ \\
\hline $\begin{array}{l}\text { Vegetasj } \\
\text { FPencaruh lingkuncan Ficik terhadan Keranaman }\end{array}$ & & $\begin{array}{l}\text { Penelitian Biomassa dan Karbon } \\
\text { Pensalliall }\end{array}$ & 98 \\
\hline 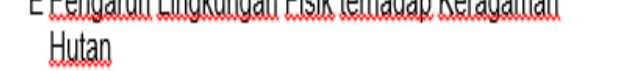 & 29 & a Penentuan sampling plot. & 98 \\
\hline BAB II STRUKTUR VEGETASI MANGROVE & 32 & a) Bentuk plot & 98 \\
\hline A Morfologi Mangrove & 34 & b) Ukuran Plot & 99 \\
\hline B Jenis - Jenis Hutan Mangrove & 43 & c) Teletiakan Flot & 100 \\
\hline CManfaat Hutan Mangrove & 45 & d) Jumlah Plot & 100 \\
\hline D Paramater dalam analisis Komunitas & 49 & b Biomassa Tegakan & 103 \\
\hline BAB III NILAI SERAPAN KARBON MANGROVE DI & 63 & a) Pengukuran Dianter & 103 \\
\hline DESA DULUPI KABUPATEN BOALEMO & 00 & b) Pengukuran Jinggi Rohon & 104 \\
\hline A Kondisis Hutan Mangrove Di Kabupaten Boaleme & 65 & c) Pengukuran Diameter Tajuk & 104 \\
\hline B Struktur vegetasi Mangrove Di Kecamatan Dulupi & 67 & c Komponen Vegetass Lainnya & 106 \\
\hline CPendugaan Nila i Biomassa Karbon Mangrove di Desa & & $d$ Baban Organik Mati & 107 \\
\hline Jabenge Boaleme & 14 & a) Kayu Mati Tegak & 108 \\
\hline Deendugaan Nilai Kandungan Karbon Mangrove di & 77 & 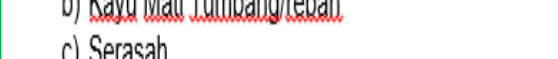 & 115 \\
\hline Lesas Labonge boalemo & & v & \\
\hline
\end{tabular}

\begin{tabular}{|lc|}
\hline & \\
BAB V TINGKAT DEGRADASI EKOSISTEM & \\
MANGROVE DI DESA TABONGO KABUPATEN & 117 \\
BOALEMO & \\
A Tingkat Degradasi Mengrove Di Desa Tabonge & 118 \\
Berdasarkan Kerapatan Spesies & \\
B Tingkat Degradasi Mengrove Di Desa Tabonge & 119 \\
Berdasarkan Luas Tutupan & 119 \\
aLuas penutupan Suatu Jenis (Ci) & 120 \\
bLuas Jutupan Relatif Suatu Jenis (RCi) & $\mathbf{1 2 6}$ \\
DAFTAR PUSTAKA & $\mathbf{1 3 2}$ \\
GLOSARIUM & $\mathbf{1 3 6}$ \\
BIOGRAFI PENULIS & \\
\hline
\end{tabular}

Gambar 1. Desain sistematika buku ajar

Sampul depan buku ajar dibuat dengan tujuan untuk menarik perhatian peserta didik, sehingga mereka termotivasi untuk membaca buku ajar. Sampul depan buku ajar berisi judul, background hutan mangrove. Pemilihan background tersebut bertujuan agar peserta didik tertarik untuk mengetahui fungsi dan mangrove 
secara ekologis dan bagaimana cara mengetahui fungsi mangrove ditinjau dari potensi mangrove mengurangi dampak perubahan iklim akibat pencemaran udara. Pada draf awal buku ajar, sampul sampul depan kurang menarik dimana tata letak gambar belum sesuai, sehingga pada draft buku ajar yang telah direvisi, sampul depan buku ajar dibuat dibuat lebih menarik. Berikut gambar dari sampul depan sebelum revisi dan sesudah revisi.
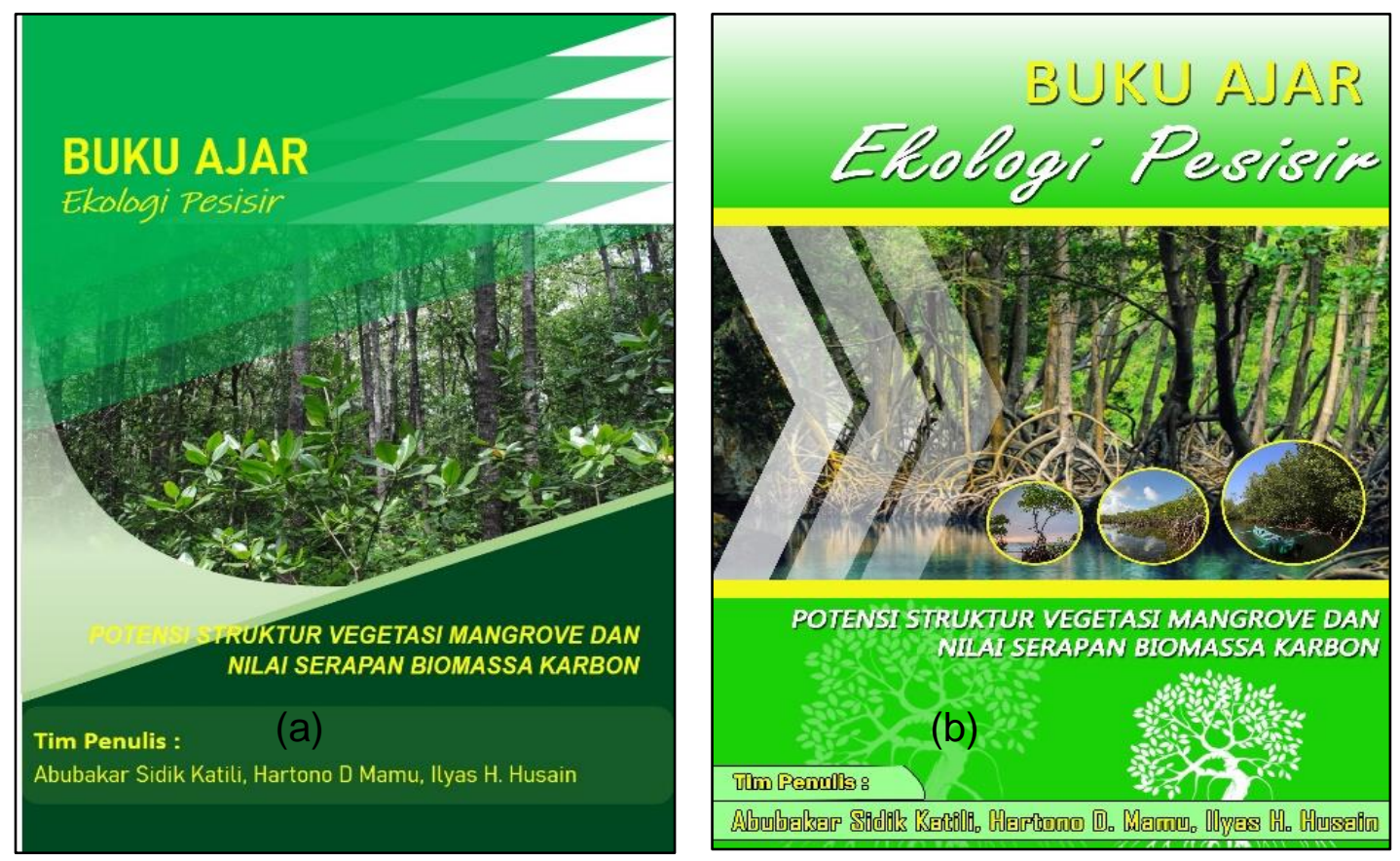

Gambar 2. Sampul depan buku ajar: (a) sebelum revisi, (b) sesudah revisi

Rancangan buku ajar yang telah dihasilkan selanjutnya diproses validasi oleh validator yang bertujuan untuk mengetahui kelayakan dari buku ajar yang dihasilkan. Validator terdiri atas 3 yakni validator ahli materi, validator ahli desain dan validator pengguna dalam hal ini adalah mahasiswa. Hasil validasi oleh validator ahli konten atau materi dengan menghitung skor setiap aspek penilaian diperoleh persentase keidealan produk buku ajar menunjukkan bahwa persentase untuk setiap aspek dari aspek format materi dengan nilai $87,5 \%$ (Sangat baik), kelayakan aspek isi materi dengan nilai $96.43 \%$ (Sangat baik), dan kualitas aspek penilaian dengan nilai $91,67 \%$ (sangat baik). Diperoleh hasil perhitungan persentase keidealan secara keseluruhan oleh ahli materi yaitu 93,75\% (sangat baik). Hasil tersebut menunjukkan bahwa persentase keseluruhan aspek dari penilaian validator ahli materi berada pada rentang $81 \%-100 \%$ dan jika konfirmasikan pada skala rentang validitas, nilai tersebut termasuk berada pada kategori sangat baik. Hasil validasi oleh validator ahli desain dengan menghitung persentase keidealan buku ajar dari aspek desain yakni sampul buku berada pada nilai 93,75\% (sangat baik), kelayakan aspek tampilan berada pada nilai 90,63\% (gangat baik). Persentase keidealan desain secara keseluruhan berada pada nilai 91,67\% (sangat baik). Hasil tersebut 
menunjukkan bahwa persentase keseluruhan aspek dari penilaian validator ahli desain berada pada rentang $81 \%-100 \%$

Hasil penilaian/validasi oleh validator pengguna yakni mahasiswa menunjukkan, rata-rata secara keseluruhan buku ajar $(X)$ yakni sebesar 37,6. Nilai tersebut lebih kecil dibandingkan dengan nilai $\mathrm{Mi}+1,80 \mathrm{SBi}(\mathrm{X}>\mathrm{Mi}+1,80 \mathrm{SBi})$, sehingga dapat dikatakan bahwa penilaian oleh mahasiswa terletak pada kategori valid. Persentase keidealan secara keseluruhan yakni sebesar 94\% (Sangat Baik), aspek kemenarikan buku ajar $95 \%$ (sangat baik), aspek kemudahan penggunaan buku ajar 92,5\% (sangat baik) dan aspek keterbacaan sebesar 97,17\% (sangat baik). Hasil tersebut menunjukkan bahwa bahwa persentase keseluruhan aspek berada dalam rentang $81 \%$ - 100\% yang berarti tingkat keidealan buku ajar sangat baik.

Ekologi pesisir merupakan mata kuliah wajib bagi mahasiswa semester $\mathrm{V}$ di program studi biologi FMIPA, Universitas Negeri Gorontalo. Dalam mata kuliah ini dideskripsikan konsep penerapan dan pengembangan prinsip-prinsip ekologi pesisir dalam kebermaknaan hidup dan penelitian (Sukarsono, 2012).

Menurut Susanto (2000) ekologi menyangkut 3 aspek pokok, yaitu: 1) deskriptif, 2) kuantitatif, dan 3) analitik-sintetik. Ekologi deskriptif menyangkut pengetahuan tentang cara hidup, yaitu meliputi tingkah laku, habitat, kondisi lingkungan hidup, hubungan dengan jenis lain, karakteristik kelompok sosialnya, dominansinya, asal mula dan suksesi pembetukan komunitasnya. Ekologi kuantitatif memberikan informasi yang menyangkut tentang ukuran-ukuran kondisi lingkungan dan batas-batas toleransi terhadap fluktuasi faktor lingkungan, jumlah, dan macam jenis yang bertahan hidup dalam habitat tertentu. Ekologi analitik-sintetik berusaha menganalisis lingkungan beserta pengaruhnya dengan cara memvariasikan kondisi faktor tertentu di bawah kondisi faktor lain yang terkontrol, menganalisis mengapa mempunyai habitat spesifik, mengapa berkembang, mengapa punah, dan mengapa beradaptasi dengan lingkungan baru.

Buku Ajar yang telah diproduksi sebagai hasil pengembangan dari riset awal terkait potensi ekosistem mangrove dalam menyerap karbon memuat materi yang dapat memperkaya buku teks pada jenjang pendidikan perguruan tinggi. Buku ajar ini dimaksutkan untuk memberikan informasi tentang pokok-pokok bahasan tertentu dalam kurikulum secara lebih luas atau lebih dalam. Buku ajar disebut juga buku pelajaran pelengkap yang berisi informasi untuk melengkapi buku pelajaran pokok. Pendapat tersebut sejalan dengan Cintamulya (2011) yang mengungkapkan bahwa buku ajar memuat materi yang dapat memperkaya dan meningkatkan penguasaan IPTEK dan keterampilan pembaca. Buku jenis ini tidak sematamata untuk peserta didik namun dapat digunakan masyarakat umum. Buku ajar digunakan pendidik untuk memperkaya proses pembelajaran. Sejalan dengan pendapat Cintamulya (2011) di atas, maka salah satu hal yang harus dikuasai oleh mahasiswa dalam perkuliahan atau pembelajaran ekologi pesisir adalah bahwa keanekaragaman hayati dan termasuk juga keanekaragaman jenis merupakan anugerah Tuhan yang perlu dijaga dan dilestrarikan. Sebagaimana umumnya ciri sebuah ilmu, ekologi 
adalah salah satu disiplin ilmu yang terus berkembang oleh karena itu pentingnya buku ajar akan terus mengalami berbagai perkembangan menuju arah perbaikan (Sukarsono, 2013). Belum tersediannya secara maksimal suatu media pembelajaran dalam bentuk buku teks terkait fugsi mangrove sebagai penyerap karbon dalam perkuliahan ekologi pesisir menjadikan suatu pengembangan buku ajar berbasis penelitian sebagai sebuah hal yang cukup penting dan dapat memperkaya pemahaman mahasiswa. Hal ini sejalan dengan tuntutan pendidikan saat ini yang menyatakan bahwa salah satu prinsip pembelajaran harus mendalam dan lebih komprehensif melalui kemampuan berpikir kritis, induktif, dan deduktif untuk menyelesaikan kesulitan yang dialami mahasiswa dalam memahami materi ekologi biasanya adalah memahami terminologi dan prinsip-prinsip mengingat tidak cukupnya ilustrasi yang dapat membantu mereka merangkai pikiran secara cepat informasi baru dengan informasi yang belum tersedia dalam pikiran. Oleh karena itu, penulis berusaha menyajikan informasi mengenai materi dalam buku ajar ini dengan beberapa tampilan gambar sehingga diharapkan materi akan lebih cepat dipahami oleh para mahasiswa.

Menurut Suhardjono (2008) paling tidak ada 3 cara yang dapat dipergunakan dosen dalam menyusun buku ajar, yaitu menulis sendiri, pengemasan kembali informasi, dan penataan kembali. Dosen umumnya mengabungkan 3 cara tersebut sesuai dengan tujuan instruksionalnya, dosen mengumpulkan berbagai informasi dari berbagai sumber, baik dari buku teks, artikel ilmiah, jurnal, dan media massa. Informasi kemudian dikemas sesuai dengan kebutuhan mahasiswa, selanjutnya ditata, dikemas, dan ditulis sebagai bahan ajar menggunakan kerangka sistematis. Buku ajar yang dikembangkan ini telah sejalan dengan pendapat Suhardjono (2008) namun memiliki nilai lebih atau tambah karena juga memuat hasil penelitian penulis sendiri. Buku ajar ini pun diperkaya dengan panduan pengamatan atau penelitian, sehingga para mahasiswa atau pembaca dapat menerapkannya atau dapat melakukan penelitian dengan merujuk pada buku ajar ini.

Pembahasan difokuskan pada penyajian dan analisis data serta revisi yang dilakukan terhadap produk pengembangan. Hasil penilaian ahli materi berdasarkan angket tertutup menunjukkan bahwa persentase yang diperoleh buku ajar adalah $93,75 \%$. Persentase tersebut bila dikonversikan ke dalam tabel konversi tingkat pencapaian skala 4 berada pada kualifikasi sangat baik. Hal ini berarti bahwa buku ajar tidak perlu direvisi. Adapun revisi-revisi yang dilakukan terhadap buku ajar berdasarkan masukan ahli materi adalah sebagai berikut: kata pengantar alangkah baiknya di awal setelah judul, perlu adanya perbaikan penulisan daftar isi, kata pengantar seharusnya membuat keterangan tentang isi buku ajar yang merupakan pengembangan pokok bahasan materi dan energy pada mata kuliah ekologi pesisir, penulisan referensi harus dicantumkan pada semua tulisan yang di kutip selanjutnya memperhatikan konsistensi penulisan. Hasil penilaian ahli desain terhadap produk pengembangan berdasarkan angket tertutup menunjukkan bahwa persentase perolehan buku ajar adalah $91,67 \%$. Hal yang sama pun bila dikonversikan ke dalam tabel konversi tingkat pencapaian skala 4, persentae ini berada pada 
kualifikasi sangat baik. Hal ini berarti bahwa buku ajar ini pun tidak perlu untuk direvisi. Adapun beberapa hal yang disarankan oleh ahli desain pembelajaran adalah perlu memperhatikan tata penulisan yang sesuai dengan kaidah, diakhir uraian materi perlu menambahkan point-poin untuk soal-soal berdasarkan indikator. Dengan demikian, revisi yang dilakukan adalah memperbaiki tata cara penulisan yang sesuai dengan kaidah penulisan, menambahkan poin-poin untuk soal-soal berdasarkan indikator yang ada pada buku ajar tersebut.

Berdasarkan hasil penilaian peserta didik dapat diidentifikasi bahwa rata-rata secara keseluruhan buku ajar (X) yakni sebesar 37,6. Nilai tersebut lebih kecil dibandingkan dengan nilai $\mathrm{Mi}+1,80 \mathrm{SBi}(\mathrm{X}>\mathrm{Mi}+1,80 \mathrm{SBi})$, sehingga dapat dikatakan bahwa penilaian oleh peserta didik terletak pada kategori valid. Selanjutnya dengan menghitung persentase keidealan produk buku ajar untuk setiap aspek maupun keseluruhan. Persentase keidealan secara keseluruhan yakni sebesar 94\% (Sangat Baik). Sementara itu untuk setiap aspek yakni aspek kemenarikan buku ajar $95 \%$ (sangat baik), kemudahan penggunaan buku ajar 92,5\% (sangat baik) dan dari aspek keterbacaan buku ajar sebesar 97,17 \% (sangat baik). Berdasarkan hasil perhitungan tersebut, terlihat bahwa presentase keseluruhan aspek dari uji kelompok kecil berada dalam rentang $81 \%-100 \%$ yang berarti tingkat keidealan buku ajar potensi ekosistem mangrove sebagai penyerap karbon dalam kategori sangat baik.

\section{KESIMPULAN}

Buku ajar yang telah dikembangkan dengan menggunakan materi nilai struktur vegetasi mangrove dan nilai serapan karbon yang merupakan hasil riset, telah teruji melalui validasi ahli desain, validasi ahli materi, dan validasi pengguna. Buku ajar ini layak untuk digunakan dalam kegiatan pembelajaran pada mata kuliah ekologi pesisir. Hasil pengembangan buku ajar ini pula memiliki kepraktisan sebagai hasil penilaian mahasiswa di program studi biologi FMIPA Universitas Negeri Gorontalo.

\section{UCAPAN TERIMA KASIH}

Ucapan terima kasih disampaikan kepada pihak-pihak yang telah berperan dan mendukung penelitian ini antara lain LPPM Universitas Negeri Gorontalo yang telah mendukung pendanaan, program studi biologi fakultas MIPA Universitas Negeri Gorontalo, yang telah memberikan dukungan adminstrasi dalam kegiatan penelitian ini, dan laboratorium biologi sebagai penyedia data pendukung dan referensi dalam penelitian ini, pemerintah desa Tabongo Kecamatan Dulupi Kabupaten Boalemo Provinsi Gorontalo.

\section{DAFTAR PUSTAKA}

Arifin, Zainal. (2009). Evaluasi Pembelajaran. Bandung : PT. Remaja Rosdakarya. Arief, A . (2003). Hutan Mangrove Fungsi dan Manfaatnya. Kanisius. Jogjakarta. 
Bismark, M. Subiandono, E. and Heriyanto, N.M. (2008). Keragaman dan potensi jenis serta kandungan karbon hutan mangrove disungai Subelen Siberut, Sumatera Barat. Pusat Litbang Hutan dan Konservasi Alam. Bogor.

Borg, Walter R, Meredith Damin Gal. (1989). Educational Recearch : An Introduction University of Oregon Seventh Edition: Boston, New York.

Cintamulya, I. (2011). Analisis Variasi Genetik Varian Jati Arboretum dengan Penanda Mikrosatelit sebagai Bahan untuk Menyusun Buku Pengayaan Kajian Dasar-Dasar Molekuler Tumbuhan.. Malang: Pascasarjana UM.

Degeng. (2001). Teori Belajar dan Strategi Pembelajaran. Surabaya: Citra Raya. (Online) :http://www.slideshare.net/bunfaris/teori-belajar-dan-pembelajarankonstruktivisme-34241799 diakses tanggal 7 Mei 2020

Donato C. Daniel, J. Boone Kauffman, Daniel Murdiyarso, Sofyan Kurnianto, Melanie Stidham dan Markku Kanninen. (2012). Mangrove Adalah Salah Satu Hutan Terkaya Karbon Di Kawasan Tropis. Brief Cifor.[Online]. Tersedia di : http://www.cifor.org/publications/pdf files/infobrief/3773-infobrief.pdf. Diakses tanggal 10 Juni 2020

Ilmiliyana, A., Muryono, M. dan Purnobasuki, H. (2012). Estimasi Stok Karbon Pada Tegakan Pohon Rhizophora stylosa Di Pantai Camplong, Sampang-Madura. Jurnal Jurusan Biologi, Fakultas Matematika dan Ilmu Pengetahuan Alam Institut Teknologi Sepuluh November.[Online]. Tersedia di :http://digilib.its.ac.id/public/ITS-Undergraduate-22852-1508100020 id.pdf.Diakses Tanggal 10 Juni 2020.

Noor, Y.R, M. Khazali dan I.N.N. Suryadiputra. (2012). Panduan Pengenalan Mangrove di Indonesia. PHKA/WI-IP, Bogor.

Prastowo, Andi. (2011). Panduan Kreatif Membuat Bahan Ajar Inovatif. Jogjakarta: Diva Press.

Rahmawati, Estiana. (2013). Pengembangan Lembar Kerja Siswa (LKS) Interaktif Berbasis Website Materi Jamur (Fungi) untuk Siswa SMA/MA Kelas X Semester I. Skripsi. Program Studi Pendidikan Biologi Fakultas Sains dan Teknologi UIN Sunan Kalijaga Yogyakarta. Yogyakarta.

Sutaryo, Dudun. (2009). Perhitungan Biomassa : Sebuah Pengantar Untuk Studi Karbon dan Perdagangan Karbon. Wetlands International Indonesia Programme. Bogor.[Online] Tersedia di :http://wetlands.or.id/PDF/buku/Penghitungan\%2520Biomassa.pdf. Diakses tanggal 25 Mei 2020.

Sukarsono. (2012). Pengantar Ekologi : Konsep, Perilaku, Psikologi dan Komunikasi.Malang: UMM Press.

Suhardjono. (2008). Menyusun Bahan Ajar Agar Tujuan Perkuliahan Tercapai dengan Lebih Menyenangkan. Makalah disajikan pada workshop penyusunan bahan ajar Hibah A2Jurusan Sipil Faklutas Teknik Universitas Brawijaya, 26 Mei.

Susanto, P. (2000). Pengantar Ekologi. Jakarta: Proyek Pengembangan Guru. 